\title{
Influence of Salt-to-Moisture Ratio on Starter Culture and Calcium Lactate Crystal Formation
}

\author{
S. Agarwal, ${ }^{\star}$ J. R. Powers, ${ }^{*}$ B. G. Swanson, ${ }^{\star}$ S. Chen, $†$ and S. Clark ${ }^{\star 1}$ \\ ${ }^{*}$ Food Science and Human Nutrition, and \\ †Biological Systems Engineering, Washington State University, Pullman 99164
}

\begin{abstract}
The occurrence of $\mathrm{L}(+)$-lactate crystals in hard cheeses continues to be an expense to the cheese industry. Salt tolerance of the starter culture and the salt-to-moisture ratio ( $\mathrm{S}: \mathrm{M})$ in cheese dictate the final $\mathrm{pH}$ of cheese, which influences calcium lactate crystal (CLC) formation. This research investigates these interactions on the occurrence of CLC. A commercial starter was selected based on its sensitivity to salt, less than and greater than $4.0 \% \mathrm{~S}: \mathrm{M}$. Cheddar cheese was made by using either whole milk (3.25\% protein, $3.85 \%$ fat) or whole milk supplemented with cream and ultrafiltered milk ( $4.50 \%$ protein, $5.30 \%$ fat). Calculated amounts of salt were added at milling $(\mathrm{pH} 5.40 \pm 0.02)$ to obtain cheeses with less than $3.6 \%$ and greater than $4.5 \% \mathrm{~S}: \mathrm{M}$. Total and soluble calcium, total lactic acid, and $\mathrm{pH}$ were measured and the development of CLC was monitored in cheeses. All cheeses were vacuum packaged and gas flushed with nitrogen gas and aged at $7.2^{\circ} \mathrm{C}$ for $15 \mathrm{wk}$. Concentration of total lactic acid in high S:M cheeses ranged from 0.73 to $0.80 \mathrm{~g} / 100 \mathrm{~g}$ of cheese, whereas that in low S:M cheeses ranged from 1.86 to $1.97 \mathrm{~g} / 100$ $\mathrm{g}$ of cheese at the end of $15 \mathrm{wk}$ of aging because of the salt sensitivity of the starter culture. Concentrated milk cheeses with low and high S:M exhibited a 30 to $28 \%$ increase in total calcium (1,242 and 1,239 mg/100 $\mathrm{g}$ of cheese, respectively) compared with whole milk cheeses with low and high S:M (954 and $967 \mathrm{mg} / 100 \mathrm{~g}$ of cheese, respectively) throughout aging. Soluble calcium was 41 to $35 \%$ greater in low S:M cheeses (low-salt whole milk cheese and low-salt concentrated milk cheese; 496 and $524 \mathrm{mg} / 100 \mathrm{~g}$ of cheese, respectively) compared with high S:M cheeses (high-salt whole milk cheese and highsalt concentrated milk cheese; 351 and $387 \mathrm{mg} / 100 \mathrm{~g}$ of cheese, respectively). Because of the lower $\mathrm{pH}$ of the low S:M cheeses, CLC were observed in low S:M cheeses. However, the greatest intensity of CLC was
\end{abstract}

Received February 15, 2008.

Accepted April 7, 2008.

${ }^{1}$ Corresponding author: stephclark@wsu.edu observed in gas-flushed cheeses made with milk containing increased protein concentration because of the increased content of calcium available for CLC formation. These results show that the occurrence of CLC is dependent on cheese milk concentration and $\mathrm{pH}$ of the cheese, which can be influenced by S:M and cheese microflora.

Key words: salt-to-moisture ratio, calcium lactate crystal, Cheddar cheese, starter culture

\section{INTRODUCTION}

Quality defects in Cheddar cheeses discourage repeat purchases by consumers. White crystals on the surfaces of Cheddar cheeses have detrimental effects on sales (McDowall and McDowell, 1939). The problem remains a challenge and an expense to cheese manufacturers (Chou et al., 2003; Swearingen et al., 2004; Agarwal et al., 2005, 2006a,b). The cost of calcium lactate crystals (CLC) to the cheese industry warrants research into intervention to reduce the occurrence of CLC on hard and semihard cheeses.

The CLC may be attributed to several variables, including differences in milk composition (Pearce et al., 1973), cheese-making procedures (Dybing et al., 1986), or aging temperature (Pearce et al., 1973; Johnson et al., 1990b; Chou et al., 2003; Agarwal et al., 2006b); growth of nonstarter lactic acid bacteria (NSLAB) in cheese during aging (Chou et al., 2003; Khalid and Marth, 1990; Somers et al., 2001); and cheese pH (Agarwal et al., 2006a). Although improved sanitation and good cheese-manufacturing practices lead to reduced NSLAB counts and a decrease in the occurrence of $\mathrm{D}(-)$ lactate crystals in cheese, in recent years there has been an increased occurrence of $\mathrm{L}(+)$-lactate crystals in Cheddar cheese (Linke, 1958; Johnson, 2004; Swearingen et al., 2004; Agarwal et al., 2006a). Calcium from cheese milk and lactate from lactose fermentation are the principal components of CLC, or more specifically, calcium lactate pentahydrate $\left[\mathrm{Ca}\left(\mathrm{CH}_{3} \mathrm{CHOH}-\right.\right.$ $\mathrm{COO})_{2} \cdot 5 \mathrm{H}_{2} \mathrm{O}$; Dybing et al., 1988; Kubantseva et al., 2004]. Increases in the occurrence of CLC are attributed to changes in cheese-manufacturing techniques, such 
Table 1. Composition of whole milk and concentrated milk used for making high- and low-salt whole milk cheeses and high- and low-salt concentrated milk cheeses (mean of 4 vats $^{1}$ )

\begin{tabular}{lcccc}
\hline Milk type & TS, $\%$ & Protein, $\%$ & Fat, \% & Lactose, \% \\
\hline Whole milk & $12.24 \pm 0.32$ & $3.25 \pm 0.14$ & $3.85 \pm 0.20$ & $4.74 \pm 0.26$ \\
Concentrated milk & $15.20 \pm 0.38$ & $4.50 \pm 0.24$ & $5.36 \pm 0.30$ & $4.78 \pm 0.18$ \\
\hline
\end{tabular}

${ }^{1}$ Means of replicate \pm SD.

as the use of UF or reverse osmosis, and the use of evaporated or NDM to increase the TS of cheese milk (Johnson, 2004; Agarwal et al., 2006a). Large concentrations of protein in cheese milk are accompanied by increased colloidal calcium (Agarwal et al., 2006a; Upreti and Metzger, 2007). Calcium in milk and cheese is present in 2 forms: soluble (dissociated from casein) and colloidal or insoluble (associated with casein). An increase in colloidal (casein-bound) calcium in cheese milk can lead to increased soluble calcium concentrations in the cheeses produced if the cheese has low $\mathrm{pH}$, because an increased quantity of colloidal calcium associated with proteins becomes soluble at low cheese $\mathrm{pH}$ (Agarwal et al., 2006a). The soluble form of calcium can readily combine with lactate to form calcium lactate. As calcium lactate concentration exceeds saturation, microcrystals of calcium lactate are formed. Microcrystals can accrue in size to form macrocrystals that are visible to the human eye (Dybing et al., 1988).

Various factors, such as cheese milk quality, the cheese-making environment, the starter culture used, cheese-making procedures, and cheese storage conditions influence the $\mathrm{pH}$ of cheese, which leads to various textural and appearance attributes in Cheddar cheese. The final $\mathrm{pH}$ of cheese is influenced by many factors, including lactose in the cheese serum, the salt-to-mois- ture ratio (S:M), starter lactic acid bacteria (SLAB) and NSLAB, and storage conditions (Turner and Thomas, 1980; Thomas and Pearce, 1981; Fox et al., 2004).

The S:M is very important for controlling the growth of SLAB and NSLAB. A salt-tolerant SLAB can significantly lower the $\mathrm{pH}$ of the cheese by fermenting available lactose to lactic acid (Turner and Thomas, 1980). Turner and Thomas (1980) reported differences in the growth and utilization of lactose at different S:M concentrations; they showed that low S:M (4\%) enabled salt-tolerant SLAB to ferment lactose and produce elevated concentrations of lactic acid. At a high S:M, SLAB were inhibited and lactose was available for any NSLAB that were present in the cheese (Turner and Thomas, 1980). Swearingen et al. (2004) also observed that SLAB used in making cheese exerted a significant influence on the occurrence of CLC in Cheddar cheese. Little previous research has directly related SLAB and $\mathrm{S}: \mathrm{M}$ to the occurrence of CLC. The objective of this study was to identify relationships among protein concentration in the cheese milk, S:M, and SLAB that affect the development of CLC. We hypothesized that cheeses made from cheese milk with increased protein concentration and a low S:M ratio would exhibit low $\mathrm{pH}$ and would develop more CLC than standard cheeses and cheeses with greater S:M. The results of this re-

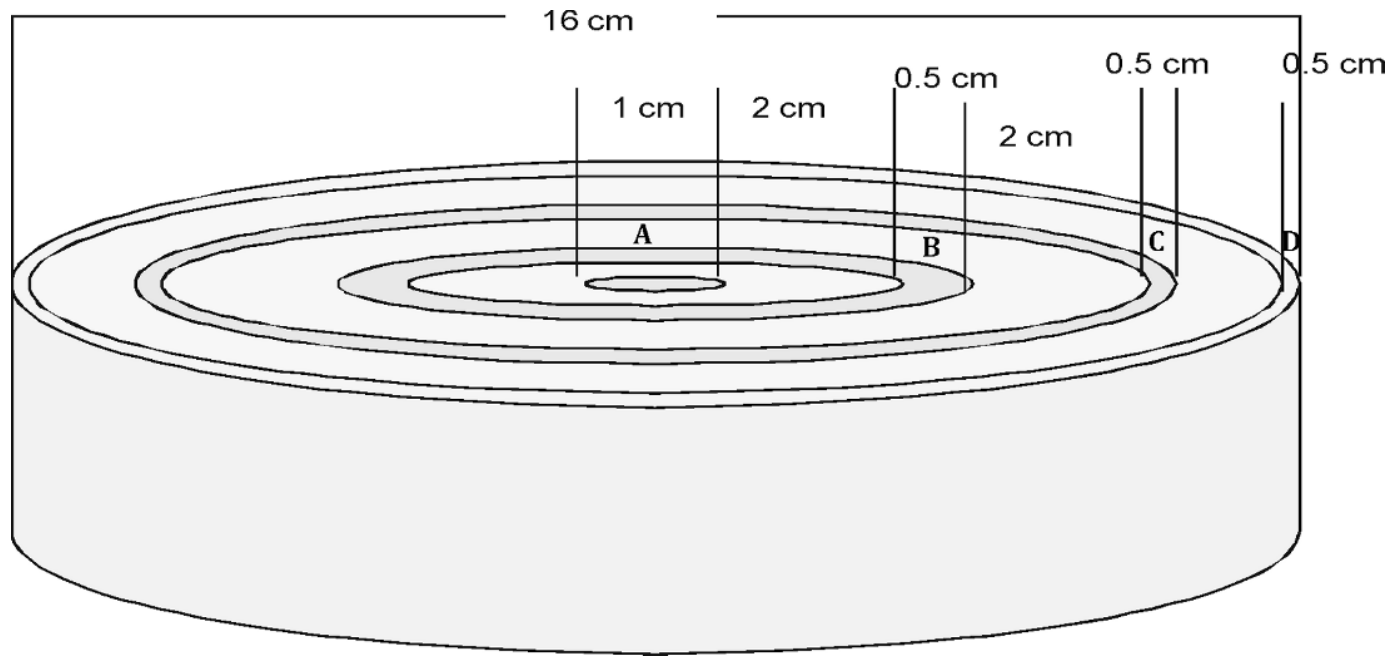

Figure 1. Schematic diagram of a cheese cylinder. Shaded areas show sampling locations. 


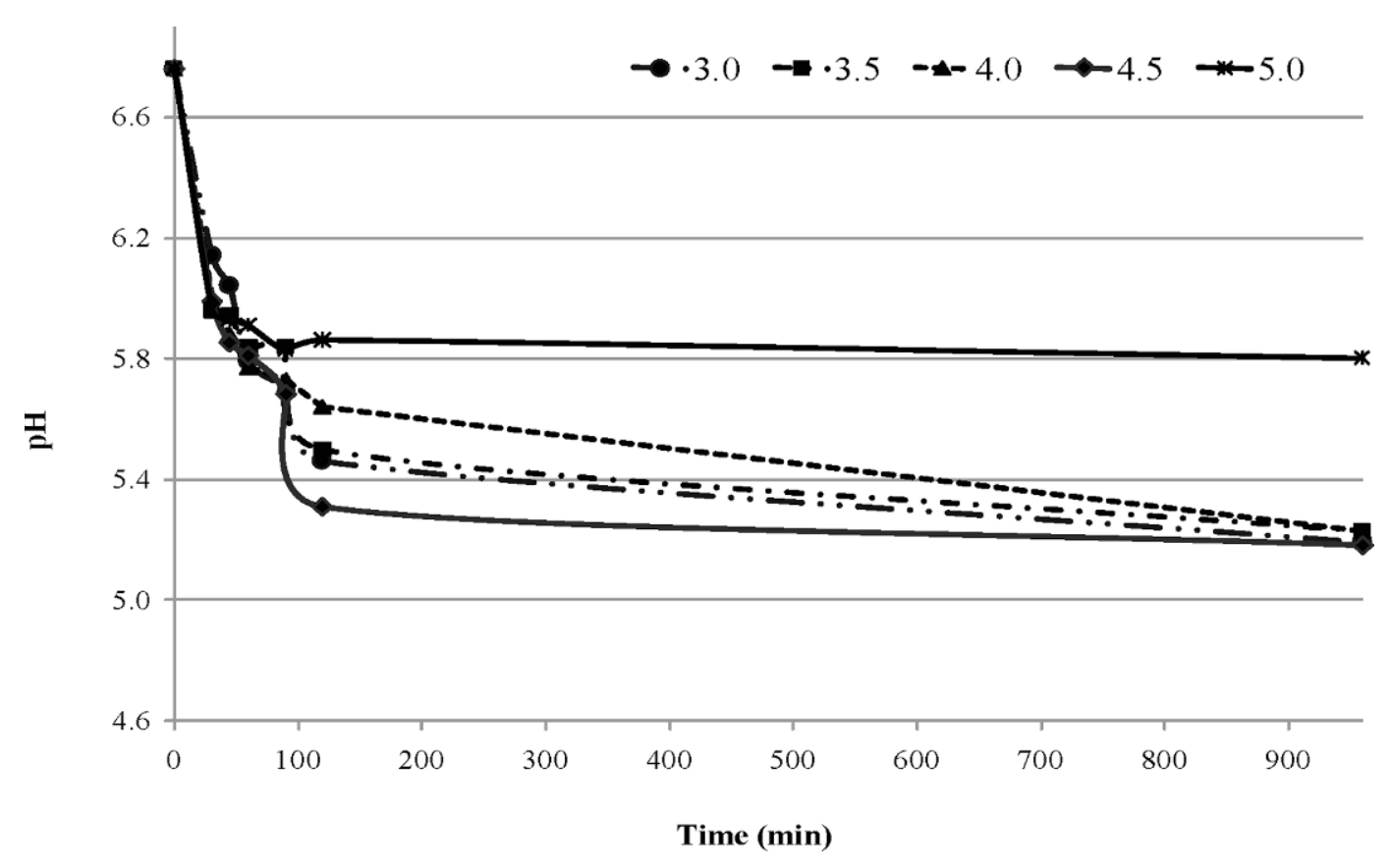

Figure 2. Effect of salt concentration (3.0, 3.5, 4.0, 4.5, and 5.0) on pH of milk inoculated with $0.1 \%$ direct vat set (DVS) culture DVS 850 and incubated for $960 \mathrm{~min}$ at $35 \pm 0.5^{\circ} \mathrm{C}$.

search will enable us to guide cheese manufacturers in cheese starter culture selection and cheese-making techniques. We also expected that differences in concentrations of calcium and lactic acid would be observed at the surface compared with at the core of the cheese, indicating the migration of calcium and lactate ions to cheese surfaces and the formation of CLC.

\section{MATERIALS AND METHODS}

\section{Selection of Starter Culture}

Three commercial direct vat set (DVS) cultures, DVS 850, R603, and R608 (Chr. Hansen, Milwaukee, WI), were tested for salt sensitivity at different salt concentration levels in whole milk. Salt (Fisher Scientific, Fair Lawn, NJ) was added to $100 \mathrm{~mL}$ of pasteurized whole milk (Wilcox Farms, Roy, WA) at the levels of 3.0, 3.5, 4.0, 4.5, and $5.0 \%$. The milk samples were incubated in a water bath (Isotemp 120, Fisher Scientific) at 35 $\pm 0.5^{\circ} \mathrm{C}$ and inoculated with $0.1 \%$ of DVS 850 , R603, and $\mathrm{R} 608$ culture. The $\mathrm{pH}$ of each milk sample was measured after $0,30,45,60,90,120$, and $960 \mathrm{~min}$. This experiment was repeated 3 times in duplicate on 3 different days. Enumeration of starter culture was not done because the aim of the trial was to find a commercial starter that would have variable sensitivity to $\mathrm{S}: \mathrm{M}$ and that could exploit the variation in $\mathrm{S}: \mathrm{M}$ in cheeses, leading to different cheese $\mathrm{pH}$ even in the same batch of cheese manufactured.

\section{Cheese Manufacture}

Four different Cheddar cheese batches were manufactured with 2 different concentrations of milk protein and 2 different S:M. The 4 different treatments included high- and low-salt whole milk cheeses (HSWMC and LSWMC, respectively) made from whole milk (3.25\% protein, $3.85 \%$ fat) and high- and low-salt concentrated milk cheeses (HSCMC and LSCMC, respectively) made from whole milk supplemented with UF milk and cream (4.5\% protein, $5.3 \%$ fat; Table 1 ). Cheeses were manufactured in duplicate, with whole milk cheeses being made from $114 \mathrm{~kg}$ of whole milk [Washington State University (WSU) Creamery] and concentrated milk cheeses being made from $68 \mathrm{~kg}$ of milk (to account for the greater yield), for a total of 8 batches of Cheddar cheese. The concentrated milk used in preparing concentrated milk cheeses was standardized by using UF skim milk (Agarwal et al., 2005), whole milk (WSU Creamery), and heavy cream (Darigold, Seattle, WA). Processing of batches of cheese was randomly distributed across days, with 2 batches of cheese made each day. The entire cheese-making process lasted for $4 \mathrm{~d}$. Two HSWMC (4.5 S:M), 2 LSWMC (3.5 S:M), 2 HSCMC (4.5 S:M), and 2 LSCMC (3.5 S:M) constituted the 8 samples. Cheeses were made by using the standard procedures followed at the WSU Creamery, with slight modifications. Mesophilic starter culture, DVS 603 (Chr. Hansen, Milwaukee, WI), at the rate of $0.1 \%$ (wt/ 


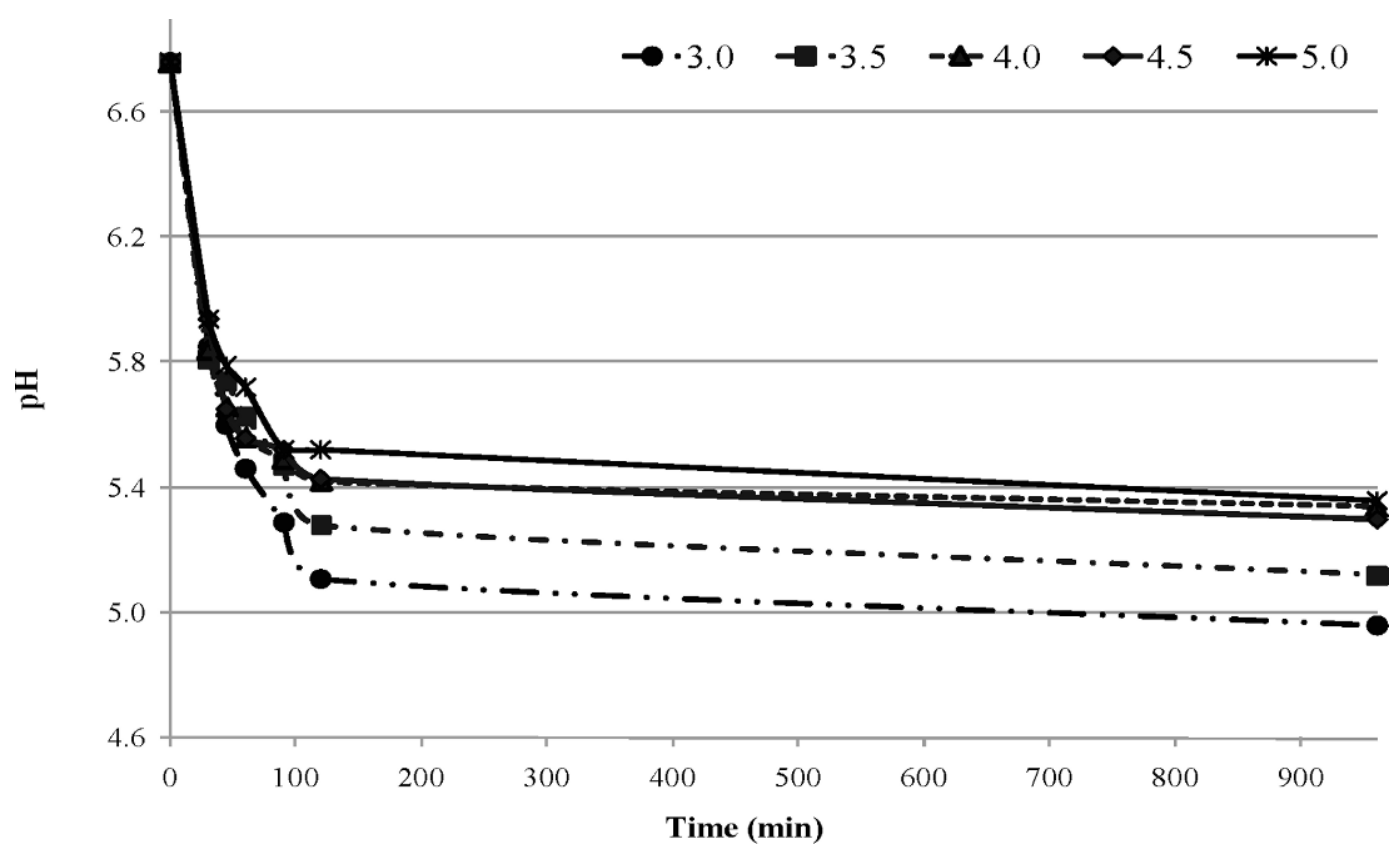

Figure 3. Effect of salt concentration (3.0, 3.5, 4.0, 4.5, and 5.0) on pH of milk inoculated with $0.1 \%$ direct vat set (DVS) culture DVS 608 and incubated for $960 \mathrm{~min}$ at $35 \pm 0.5^{\circ} \mathrm{C}$.

wt) was added at $31^{\circ} \mathrm{C}$ to milk. The curds were cooked by raising the temperature from 31 to $38^{\circ} \mathrm{C}$ at the rate of $1^{\circ} \mathrm{C}$ every 5 min over a 30 -min period. The curds and whey were stirred at $38^{\circ} \mathrm{C}$ for 45 min before draining, at whey $\mathrm{pH}$ 6.20. The cheese was cheddared until a $\mathrm{pH}$ of 5.45 was reached and then milled to a size of $1 \times 2$ $\mathrm{cm}$ and mixed with salt $(2.95 \% \mathrm{wt} / \mathrm{wt}$ of cheese curd for high S:M cheeses and $2.29 \% \mathrm{wt} / \mathrm{wt}$ for low S:M cheeses).

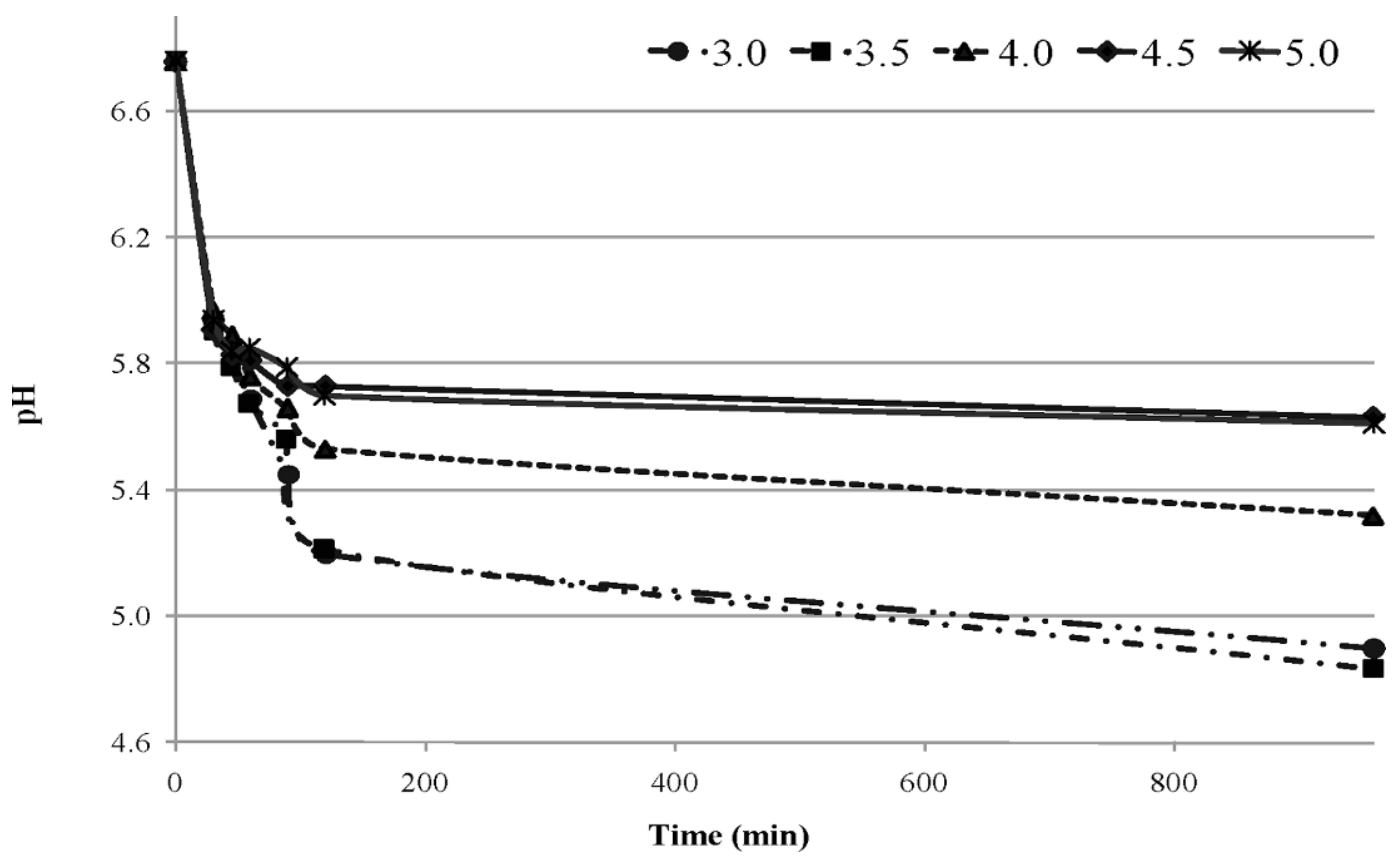

Figure 4. Effect of salt concentration (3.0, 3.5, 4.0,4.5, and 5.0) on pH of milk inoculated with $0.1 \%$ direct vat set (DVS) culture DVS 603 and incubated for $960 \mathrm{~min}$ at $35 \pm 0.5^{\circ} \mathrm{C}$. 
Table 2. Composition of low and high salt-to-moisture ratio (S:M) ratio (\%) cheeses made from whole milk and UF milk at wk 1, 10, and $15^{1}$

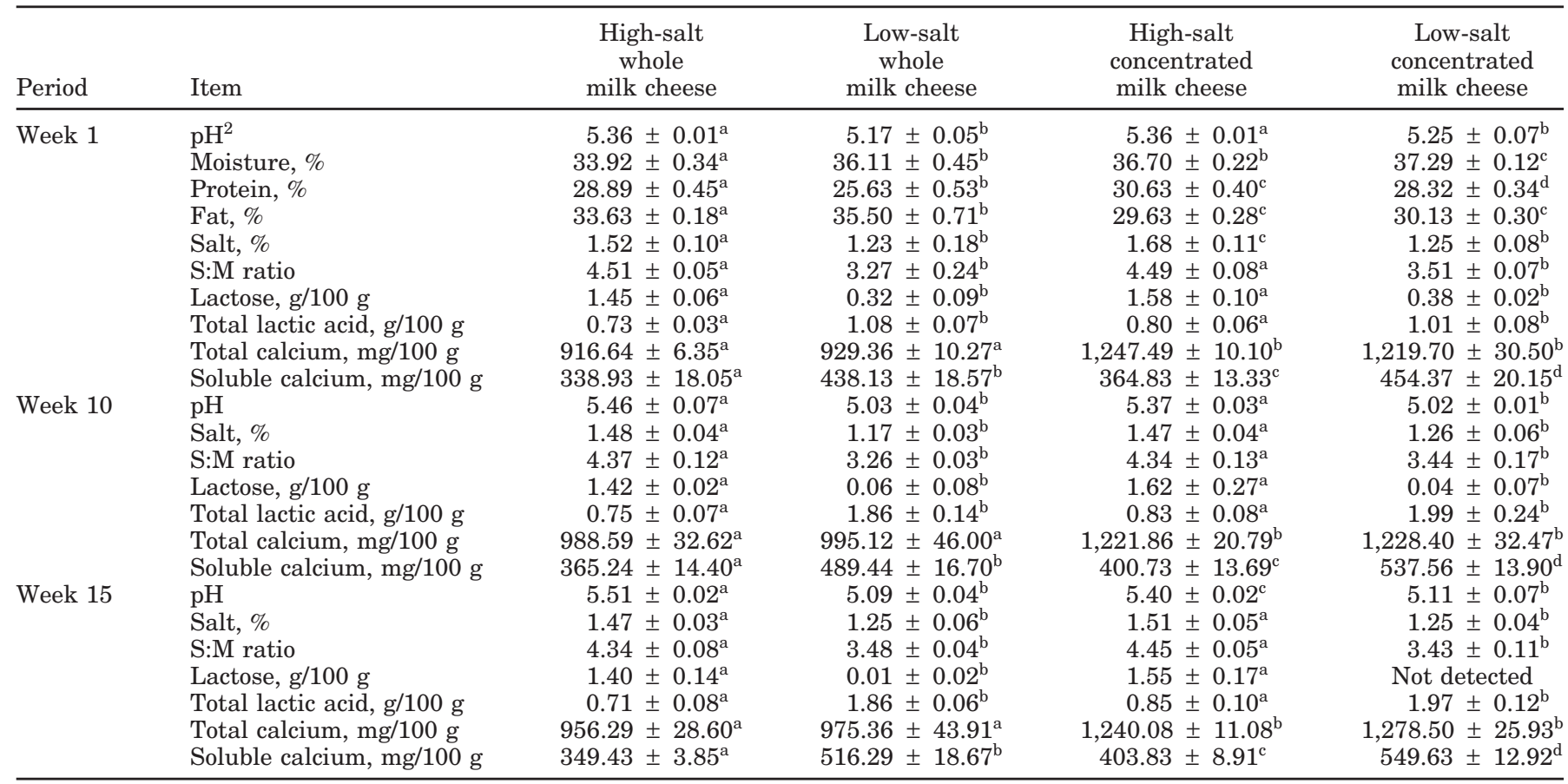

\footnotetext{
${ }^{\mathrm{a}-\mathrm{d}}$ Means within the same category ( $\mathrm{pH}$, moisture, protein, fat, salt, S:M, lactose, total lactic acid, total calcium, soluble calcium) sharing common superscripts are similar $(P>0.05)$.

${ }^{1}$ All values are means of vacuum-packaged and gas-flushed packaged cheeses because a significant difference was not found between vacuum-packaged and gas-flushed packaged cheeses (means of replicates $\pm \mathrm{SD}$ ).

${ }^{2}$ Observations taken $1 \mathrm{~d}$ after cheese manufacture.
}

An increased percentage of salt was used as compared with traditional cheese making $(2.0 \% \mathrm{wt} / \mathrm{wt}$; Robinson and Wilbery, 1998) because of increased loss of salt during salting in small-scale cheese-making batches. The cheeses were pressed in a pneumatic cheese press at $3.79 \times 10^{5} \mathrm{~Pa}$ for $16 \mathrm{~h}$. The cheeses were cut in 850 g cylinders and were vacuum packaged (model X180, Koch Supplies Inc., Kansas City, MO) in $25.4 \times 33.0$ $\mathrm{cm}, 3$-mil high-barrier nylon-ethyl vinyl alcohol-polyethylene vacuum pouches (Koch Supplies Inc.). The cheeses were then stored at $7.2^{\circ} \mathrm{C}$ for $1 \mathrm{wk}$, and half the cheese blocks were randomly selected, opened, gas flushed with nitrogen gas, and then aged at $7.2^{\circ} \mathrm{C}$ for $15 \mathrm{wk}$ along with the rest of the cheese blocks that were vacuum packaged.

Samples from cheese cylinders (diameter $16 \mathrm{~cm}$ ) were cut in 4 concentric circles by using precut cardboard pieces covered with aluminum foil at fixed distances from the center of the cheese cylinder (Figure 1) at wk 1,10 , and 15 . First, a sample ring of $0.5-\mathrm{cm}$ radius was cut from the center of the cheese, which was followed by another concentric ring of 2-cm thickness that was discarded. This procedure was repeated until 4 sample rings resulted, including the outermost ring of $0.5-\mathrm{cm}$ thickness (Figure 1). These concentric sample rings were shredded with a food processor (Cuisinart, East Windsor NJ) and packaged in Ziploc Freezer Bags (S C Johnson, Racine, WI) and stored at $-26^{\circ} \mathrm{C}$ before analysis.

\section{Compositional Analyses}

All compositional analyses were conducted in duplicate in wk 1, 10, and 15. Milk was analyzed for TS by using a forced-draft oven (Marshall, 1992), protein was analyzed by using a protein analyzer (Udy Corporation, Fort Collins, CO), and fat was analyzed according to the Babcock method (Marshall, 1992). Cheeses were analyzed for moisture (Marshall, 1992), salt by a Corning Salt Analyzer (Marshall, 1992), and $\mathrm{pH}$ by using a pH meter (Accumet AP61, Fisher Scientific) with an Accumet electrode (serial no. 208804, Fisher Scientific) calibrated with pH 4 and 7 buffers (Fisher Scientific). The total lactic acid concentration in cheese was determined by using an enzyme assay (Severn et al., 1986). Total and soluble calcium were determined by atomic absorption spectroscopy (Agarwal et al., 2006a). Lactose was measured with R-Biopharm Enzymatic Bio- 


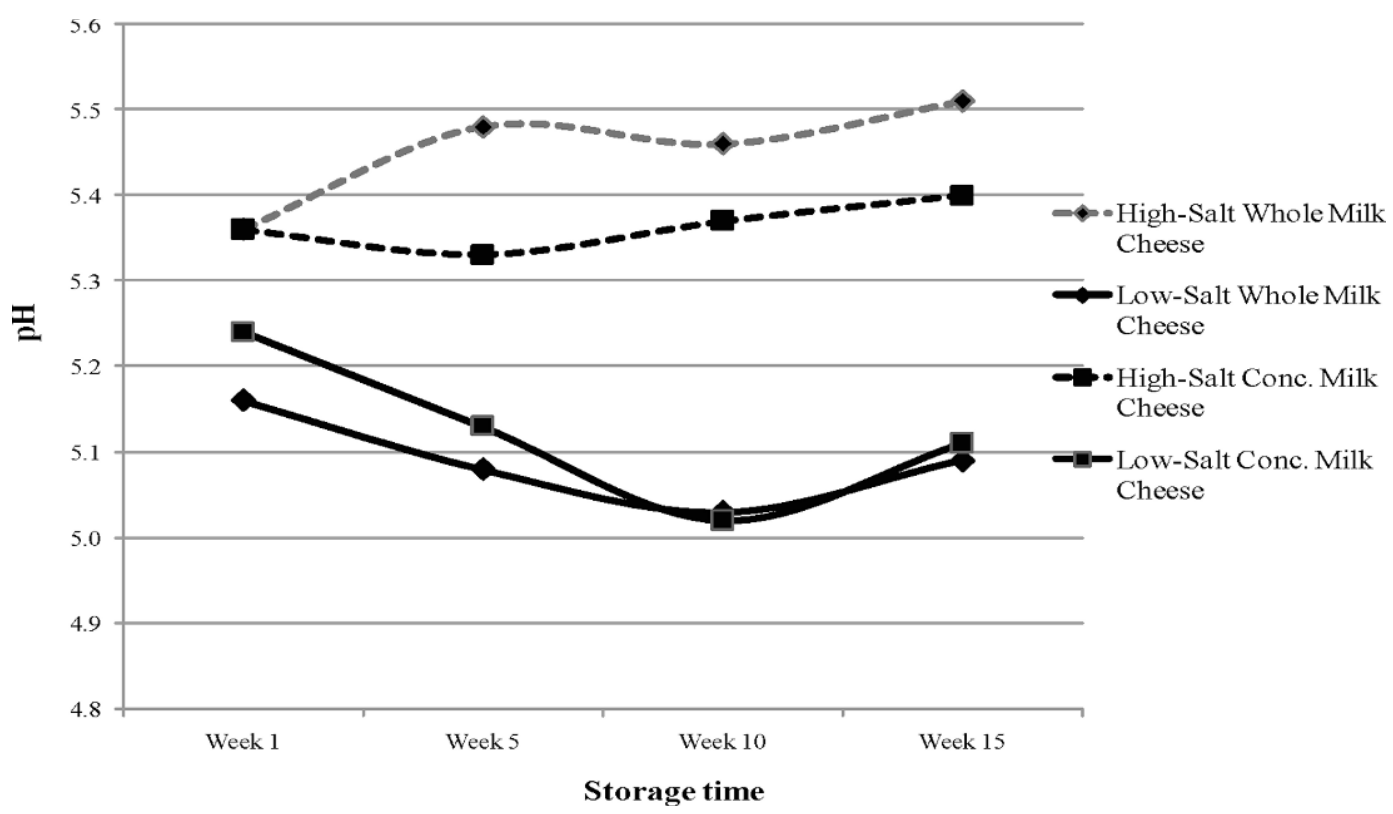

Figure 5. Changes in $\mathrm{pH}$ of high- and low-salt cheeses stored at $7.2^{\circ} \mathrm{C}$ for $15 \mathrm{wk}$ (mean of vacuum-packaged and gas-flushed packaged cheese; mean of duplicates).

analysis test kits (Enzymatic Bioanalysis/Food Analysis Test Kits, Boehringer Mannheim, Darmstadt, Germany) following the instructions provided by the manufacturer. Intensity of the occurrence of CLC was measured by using the scale developed by Agarwal et al. (2005). White crystals on the surface of cheeses were analyzed for total lactic acid by using an enzyme assay (Severn et al., 1986)

\section{Statistical Analysis}

Effects of milk type, S:M, packaging, and distance from the edge of a cheese cylinder on total calcium, soluble calcium, total lactic acid, and salt content of the cheeses were studied. The design was a split-plot design with repeated measures (Kuehl, 2000). The whole-plot design structure was completely randomized because

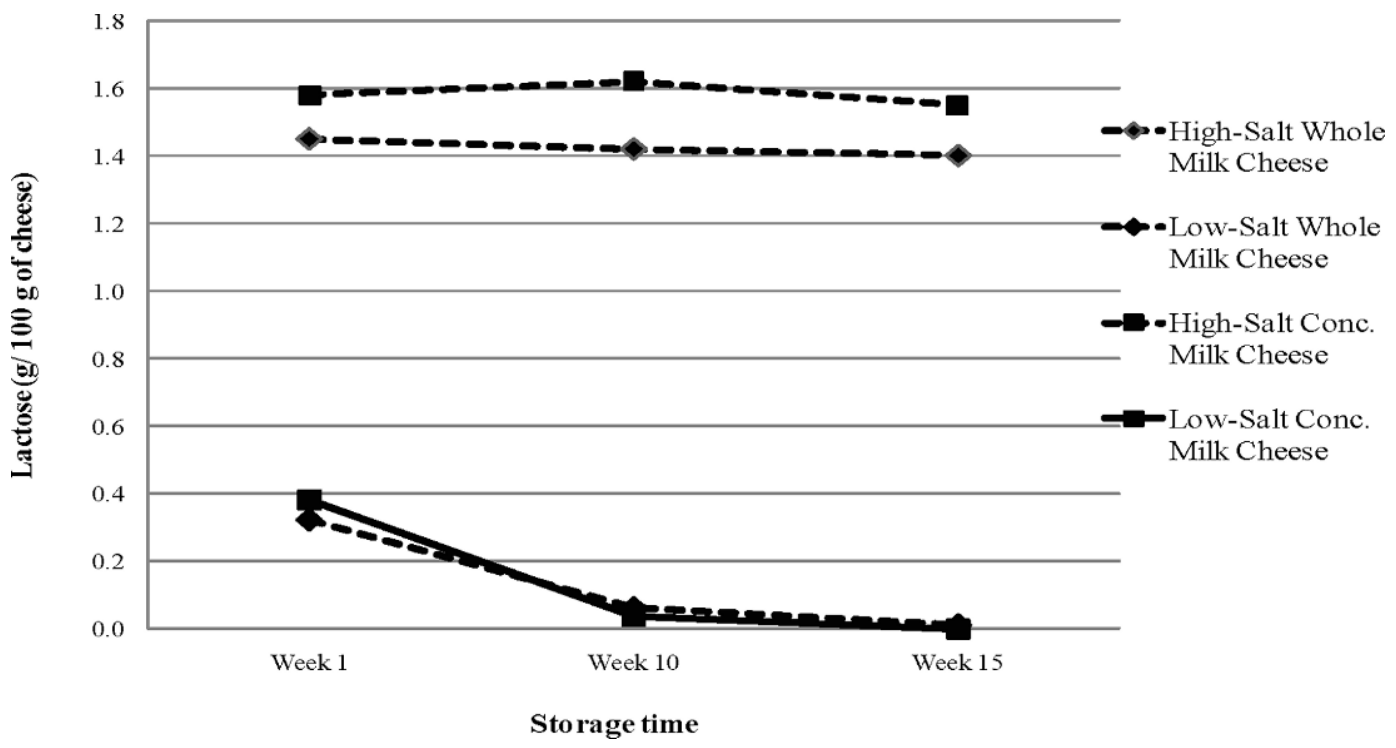

Figure 6. Changes in lactose concentration of high- and low-salt cheeses stored at $7.2^{\circ} \mathrm{C}$ for 15 wk (mean of vacuum-packaged and gasflushed packaged cheese; mean of duplicates). 


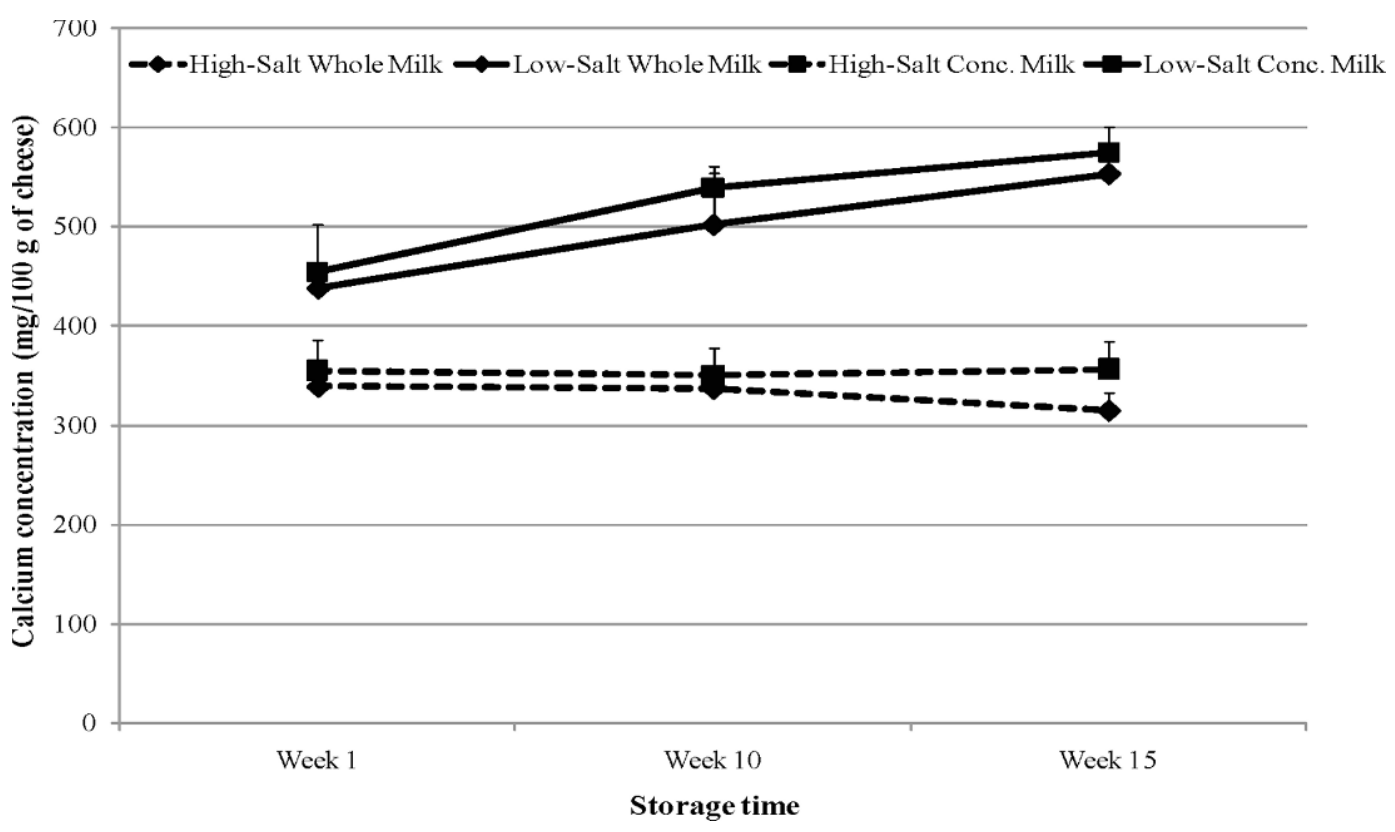

Figure 7. Changes in soluble calcium concentration of high- and low-salt cheeses stored at $7.2^{\circ} \mathrm{C}$ for 15 wk (mean of vacuum-packaged and gas-flushed packaged cheese; mean of duplicates).

the cheese batches were replicated with a one-way treatment structure (milk type). The subplot structure was a randomized complete block design with a 3 -way treatment structure (salt, packaging, and time). The repeated measure was represented by the position sampled on the cheese cylinder. Least squares means for mean comparison were used to determine significant differences at $P=0.05$.

\section{RESULTS AND DISCUSSION}

\section{Starter Culture Selection}

As expected, acid production rate of the starter bacteria was influenced by salt, which influenced the final $\mathrm{pH}$ of the milk. Starter culture DVS 850 was the least salt tolerant of the 3 starter cultures tested. The lowest $\mathrm{pH}$ attained for DVS 850 was approximately $\mathrm{pH} 5.2$ between 3.0 to $4.5 \%$ salt concentration, whereas $\mathrm{pH}$ ranged from 5.8 to 5.9 at $5.0 \%$ salt concentration (Figure 2). Starter culture DVS 608 was the most salt tolerant of the 3 starter cultures tested. The DVS 608 starter culture attained a $\mathrm{pH}$ of 5.0 at $3.0 \%$ salt concentration and approximately $\mathrm{pH} 5.4$ at $5.0 \%$ salt concentration (Figure 3). The mean $\mathrm{pH}$ of milk incubated with starter culture DVS 603 at 3.0 and $3.5 \%$ salt concentrations were 4.8 to 4.9 , but at 4.5 and $5.0 \%$ concentrations, mean $\mathrm{pH}$ of milk reached only $\mathrm{pH} 5.6$ at the end of 960 min of incubation (Figure 4). The inhibition of starter culture DVS 603 at salt concentrations greater than
$4.0 \%$, while remaining uninhibited at salt concentrations below $4.0 \%$, made it an ideal starter to study the impact of salt variation on the final $\mathrm{pH}$ of the cheese. Starter culture DVS 603 was selected for conducting cheese trials to observe the effect of salt on cultures, final $\mathrm{pH}$ of the cheese after pressing, and subsequent impact on the occurrence of CLC.

\section{Effects of Cheese Milk and Salt on Cheese Composition}

The effects of cheese milk composition and S:M on final cheese composition were significant. As expected, greater S:M cheeses (HSWMC and HSCMC) had significantly high S:M compared with low S:M cheeses (LSWMC and LSCMC; Table 2). Mean S:M in high-salt cheeses analyzed at wk 1 ranged from 4.48 to 4.55 , whereas in low-salt cheeses S:M ranged from 3.27 to 3.52. Mean moisture content in HSWMC (33.92\%), LSWMC (36.11\%), HSCMC (36.70\%), and LSCMC $(37.29 \%)$ after 1 wk of storage revealed increased moisture content in cheeses with low S:M compared with corresponding cheeses with high S:M. The decreased moisture content in high S:M cheeses compared with low S:M cheeses can be explained by the fact that syneresis is enhanced by salt; more serum was lost during pressing of cheeses with high salt content compared with those with low salt content.

Protein concentration was significantly $(P<0.05)$ higher in high S:M cheeses than in low S:M cheeses. The 


\section{A.}

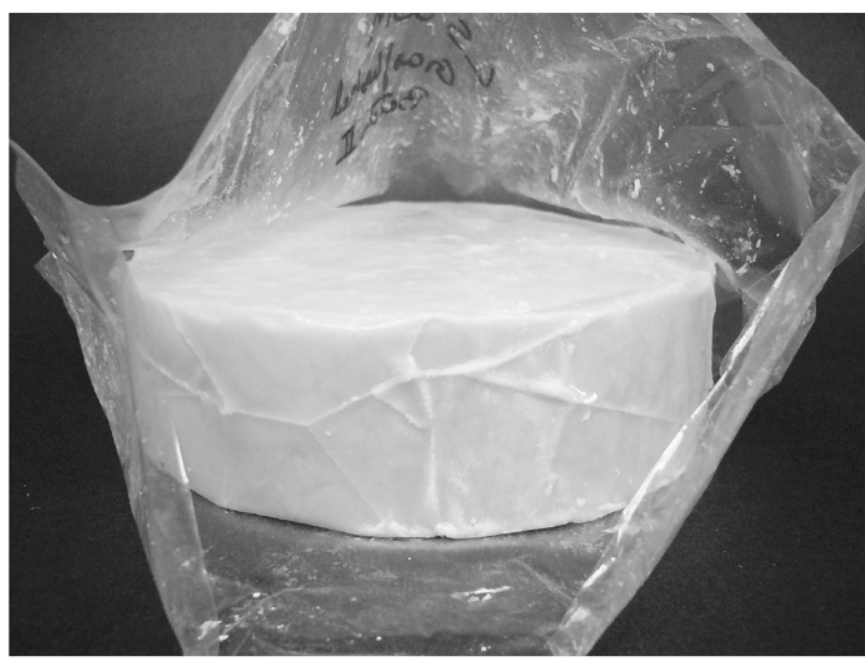

B.

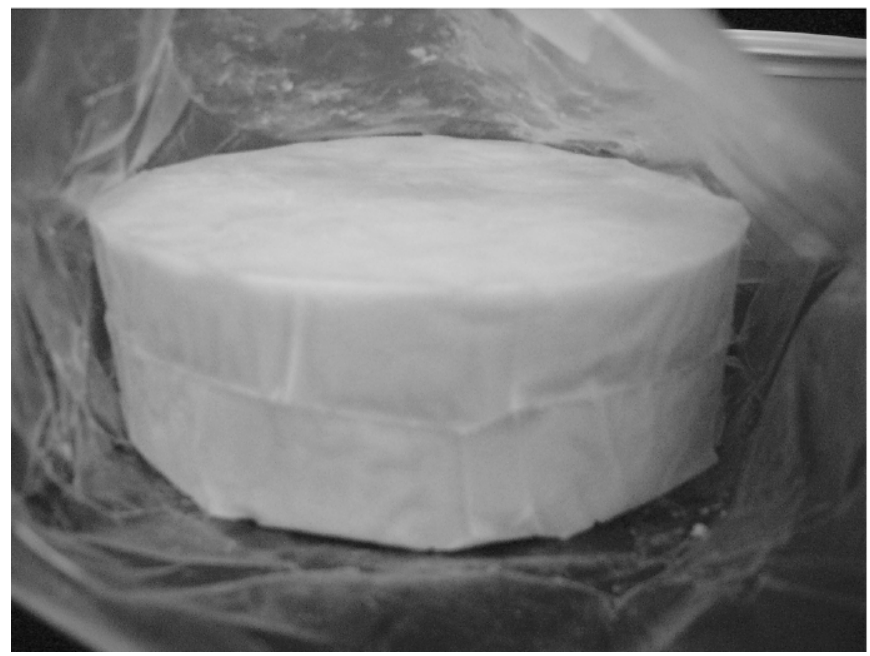

Figure 8. Comparison of calcium lactate crystals observed in (A) cheeses with low salt and (B) cheeses with high salt.

increased protein concentration in high S:M cheeses can be explained by the decreased moisture content compared with low S:M cheeses. As expected, the use of UF milk had a significant $(P<0.05)$ effect on protein concentration as well. The HSCMC (30.63\%) and LSCMC (28.32\%) had significantly increased protein concentrations compared with HSWMC $(28.89 \%)$ and LSWMC (25.63\%; Table 2). Similar results were obtained by Agarwal et al. (2006a), Acharya and Mistry (2004), and Jensen et al. (1987), in which the authors saw an increase in protein concentration of cheeses manufactured with cheese milk supplemented with UF milk. Mean fat content in HSWMC (33.63\%) and
LSWMC (35.50\%) was higher than in HSCMC (29.63\%) and LSCMC (30.13\%). This can be explained by the increased fat loss during cheese making, because cream was used to standardize the fat-to-protein ratio.

\section{Effect of Cheese Milk, Salt, and Aging on pH}

The $\mathrm{pH}$ of cheese was significantly $(P<0.05)$ influenced by salting rate and was closely related to the amount of lactic acid that developed. The mean $\mathrm{pH}$ of high S:M cheeses (HSWMC and HSCMC) at the end of 1 wk of aging decreased to only 5.35 and 5.37 compared with low S:M cheeses (LSWMC and LSCMC; 5.17 and 5.25; Table 2). The higher $\mathrm{pH}$ of LSCMC compared with LSWMC at the end of $1 \mathrm{wk}$ of aging can be explained by the increased concentrations of protein and calcium in concentrated milk, which increased the buffering capacity of the concentrated milk cheeses, although LSWMC and LSCMC had comparable concentrations of total lactic acid. A slower decrease of $\mathrm{pH}$ in cheeses having increased concentrations of calcium and phosphorus was also observed by Upreti and Metzger (2007). The $\mathrm{pH}$ of all the cheeses changed throughout the aging process. In low S:M cheeses (LSWMC and LSCMC), the $\mathrm{pH}$ decreased for the first $10 \mathrm{wk}$ and then began increasing slowly, whereas in HSWMC and HSCMC, an increase in $\mathrm{pH}$ was observed throughout the aging process (Figure 5). Greater $\mathrm{pH}$ (5.3 to 5.5) were observed in cheeses having high $\mathrm{S}: \mathrm{M}$, compared with the low $\mathrm{pH}$ (4.9 to 5.0) in cheeses having low S:M, after 15 wk of aging. Similar observations of changes in $\mathrm{pH}$ during decreased and increased $\mathrm{pH}$ during the aging of Cheddar cheese are well established (Swearingen et al., 2004; Upreti and Metzger, 2007). In the present study, the difference in $\mathrm{pH}$ of cheeses was due to inhibition of the starter culture (DVS 603) at high S:M. Elevated lactose concentrations in high S:M cheeses (HSWMC and HSCMC) after $15 \mathrm{wk}$ of aging confirmed the inhibition of the starter culture. In contrast, the absence of lactose in low S:M cheeses (LSWMC and LSCMC) showed that the starter cultures were active and that they metabolized the available lactose (Figure 6).

Several authors have documented the influence of salt on $\mathrm{pH}$ of Cheddar cheese. A correlation $(\mathrm{r}=0.94)$ between $\mathrm{S}: \mathrm{M}$ and cheese $\mathrm{pH}$ was shown by Thomas and Pearce (1981) during the first $2 \mathrm{wk}$ of aging. The authors also suggested that at low S:M $(<4.0)$, all the lactose present in the cheese will be used by cheese microflora, resulting in the lowest possible $\mathrm{pH}$. Upreti and Metzger (2007) showed that cheeses having high S:M (6.4) had higher $\mathrm{pH}$ compared with cheeses with low S:M (4.8) during 48 wk of aging. Similar results were shown by O'Connor (1974) when 8-wk-old Cheddar cheese with low S:M of 1.4 to 4.9 had low pH (ranging from 5.08 to 
Table 3. Description of the occurrence of calcium lactate crystals (CLC) in different cheeses during aging

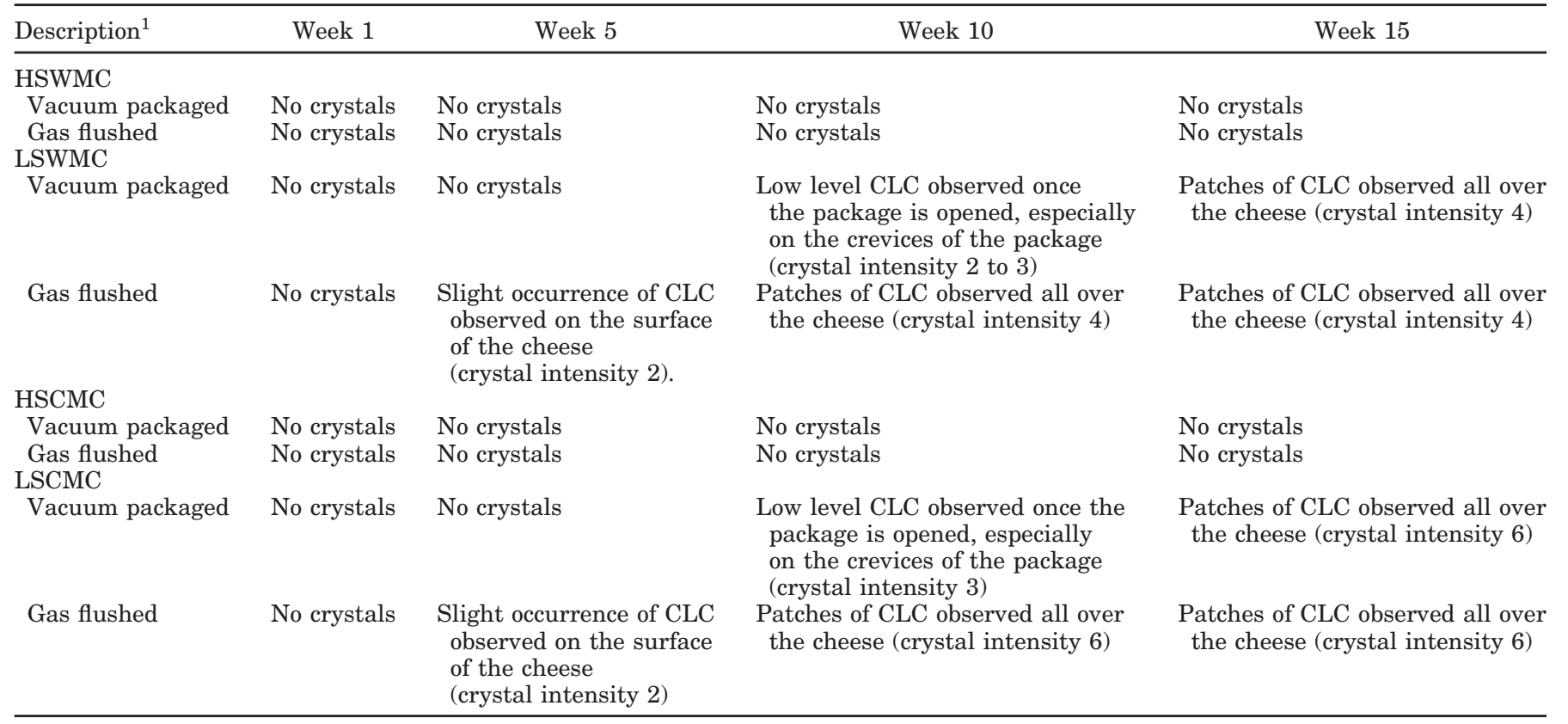

${ }^{1} \mathrm{HSWMC}=$ high-salt whole milk cheese; LSWMC = low-salt whole milk cheese; HSCMC = high-salt concentrated milk cheese; LSCMC = low-salt concentrated milk cheese.

5.12), whereas cheeses with greater S:M (6.3 to 8.3) resulted in cheeses with high $\mathrm{pH}$ (ranging from 5.41 to 5.49). The fact that different starter cultures having different salt tolerances and different SLAB are used in research explains why lower $\mathrm{pH}$ can be seen in cheeses having S:M of 4.8 than in cheeses having S:M of 6.3 to 8.3 (O’Connor, 1974; Upreti and Metzger, 2007).

\section{Effect of Cheese Milk, Salt, and Aging on Lactose and Lactic Acid}

Lactose and total lactic acid content in cheese significantly $(P<0.05)$ differed among cheeses with different S:M. As expected, increased lactose content was observed in high S:M cheeses (HSWMC and HSCMC; 1.40 to $1.55 \mathrm{~g} / 100 \mathrm{~g}$ of cheese) compared with negligible amounts of lactose in low S:M cheeses (LSWMC and LSCMC; lower than $0.01 \mathrm{~g} / 100 \mathrm{~g}$ of cheese; Figure 6). The average lactic acid concentration of high S:M cheeses (HSWMC and HSCMC; 0.73 and $0.80 \mathrm{~g} / 100 \mathrm{~g}$ of cheese) at the end of 1 wk of pressing was lower than that of low S:M cheeses (LSWMC and LSCMC; 1.08 and $1.01 \mathrm{~g} / 100 \mathrm{~g}$ of cheese), likely because of inhibition of SLAB (Table 2). A correlation $(\mathrm{r}=0.91)$ was observed between S:M and the amount of lactic acid present in cheeses after 15 wk of aging. The amount of total lactic acid in low S:M cheeses (LSWMC and LSCMC; 1.86 to $1.97 \%$ ) was more than twice the amount of total lactic acid present in high S:M cheeses (HSWMC and
HSCMC; 0.71 and $0.85 \%$ ) after 15 wk of aging (Table 2). Similar results were observed by Upreti et al. (2006), who observed that cheeses with high S:M had significantly lower total lactic acid concentrations than cheeses with low S:M. Both SLAB and NSLAB have the ability to convert lactose to lactic acid in cheese during aging (Thomas and Crow, 1983; Shakeel Ur et al., 2000; Agarwal et al., 2006b), but the presence of increased lactose does not always guarantee an increased amount of lactic acid (Blake et al., 2005). Salt influences the water activity $\left(a_{\mathrm{w}}\right)$, thus influencing the growth of SLAB and NSLAB (Thomas and Pearce, 1981). Knowing the salt-tolerance level of SLAB used in cheese making can enable manufacturers to salt appropriately to control residual lactose and subsequent CLC formation.

\section{Effect of Cheese Milk, Salt, and Aging on Total and Soluble Calcium}

Milk concentration had a significant $(P<0.05)$ effect on total calcium concentration of cheeses. Mean total calcium content in standard milk cheeses (HSWMC and LSWMC) was 953.84 and $966.61 \mathrm{mg} / 100 \mathrm{~g}$ of cheese, lower than in concentrated milk cheeses (HSCMC and LSCMC; $1,239.44$ and $1,242.20 \mathrm{mg} / 100 \mathrm{~g}$ of cheese), showing that concentration of cheese milk leads to increased concentration of total calcium in cheeses. Lee et al. (2005) also showed that cheeses made from reverse 


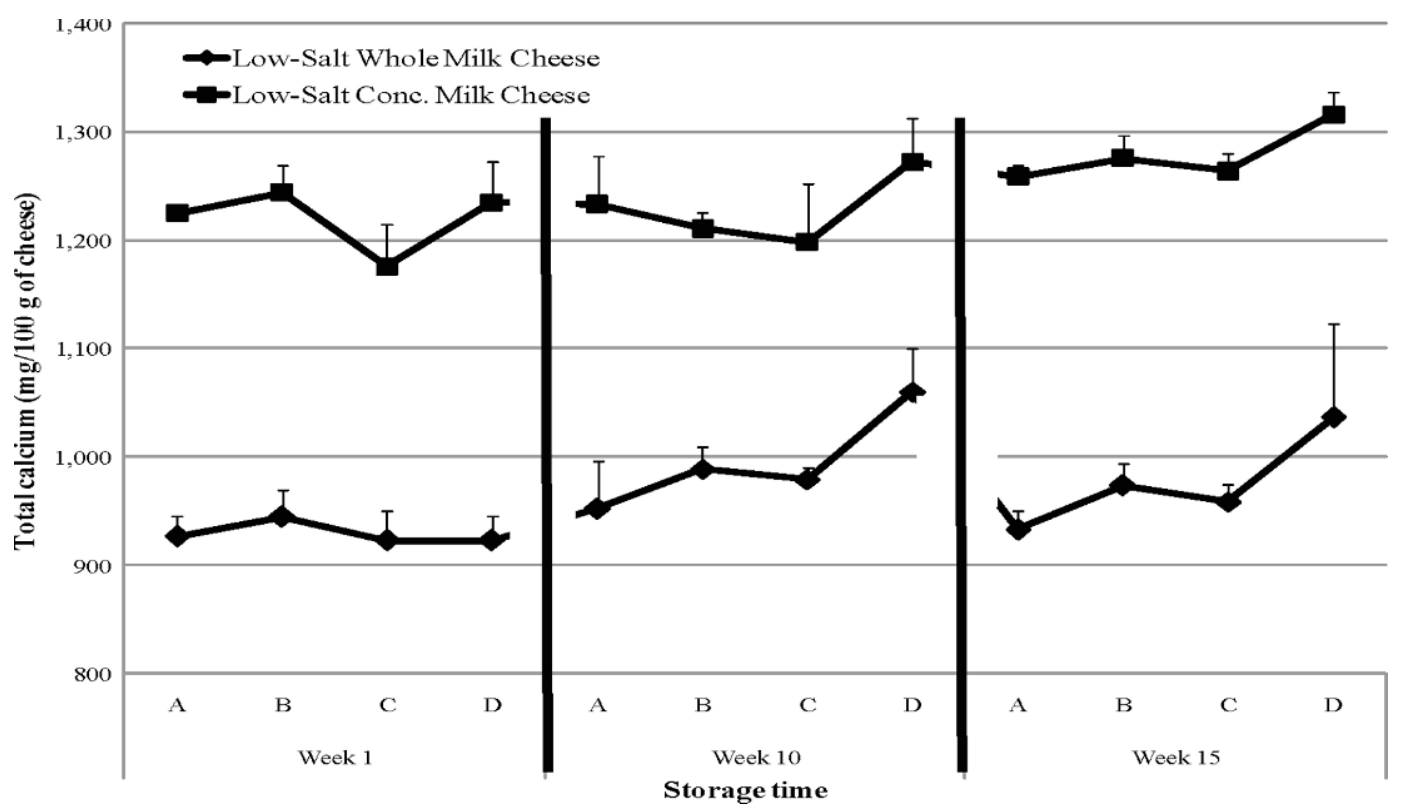

Figure 9. Changes in total calcium concentration in low-salt whole milk and low-salt concentrated milk cheeses at different positions in the cheese cylinder (with A being the innermost sample and D being the surface) throughout 15 wk of storage (mean of vacuum-packaged and gas-flushed packaged cheese; mean of duplicates).

osmosis-treated milk contained increased protein and total calcium compared with cheeses made from standard milk. Similar results were obtained by Agarwal et al. (2006a), in which cheeses manufactured from milk concentrated with either NDM or UF milk had increased protein and total calcium concentrations. However, S:M had no significant effect on total calcium of either whole milk or concentrated milk cheeses. The

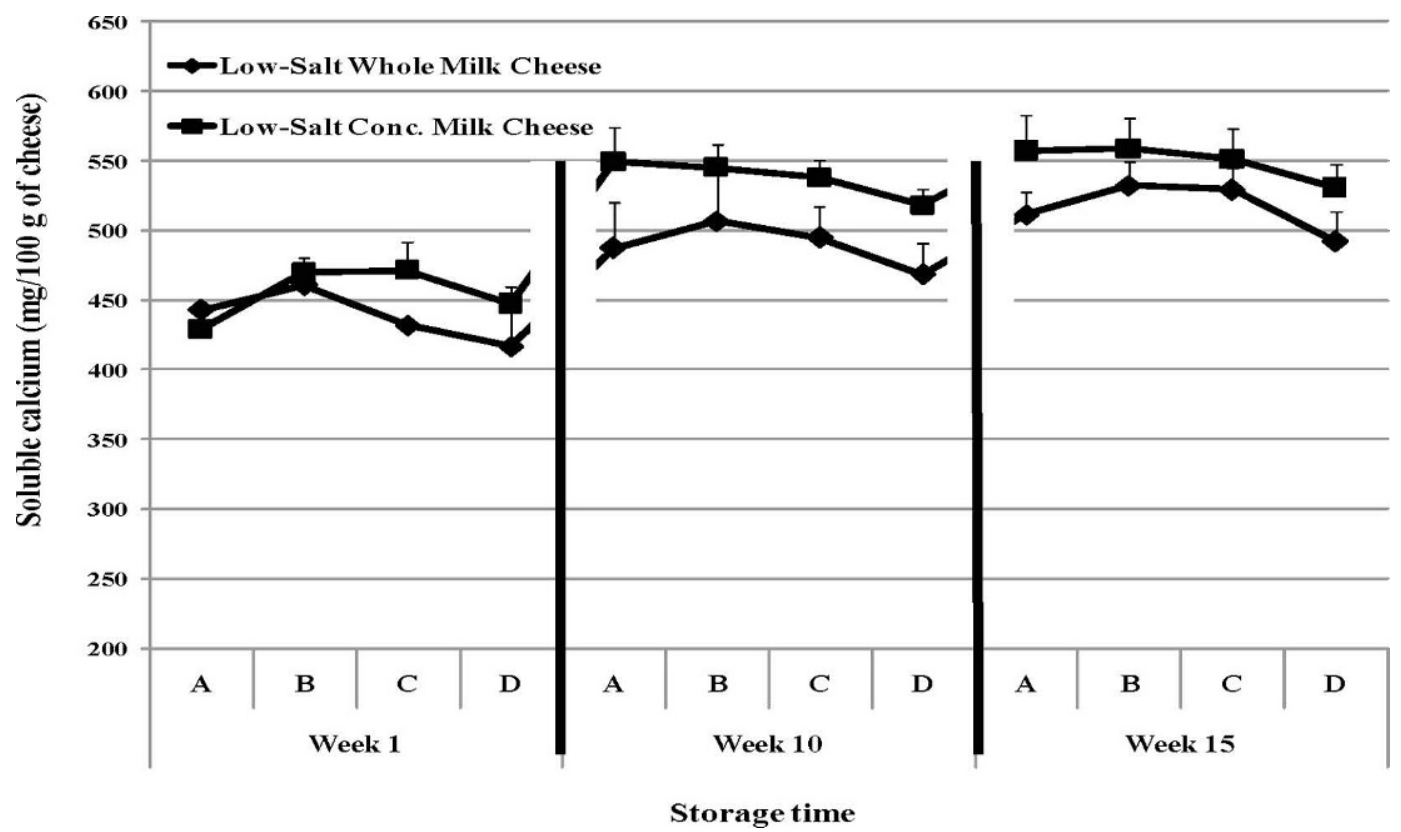

Figure 10. Changes in soluble calcium concentration in low-salt whole milk and low-salt concentrated milk cheeses at different positions in the cheese cylinder (with A being the innermost sample and D being the surface) throughout 15 wk of storage (mean of vacuum-packaged and gas-flushed packaged cheese; mean of duplicates). 


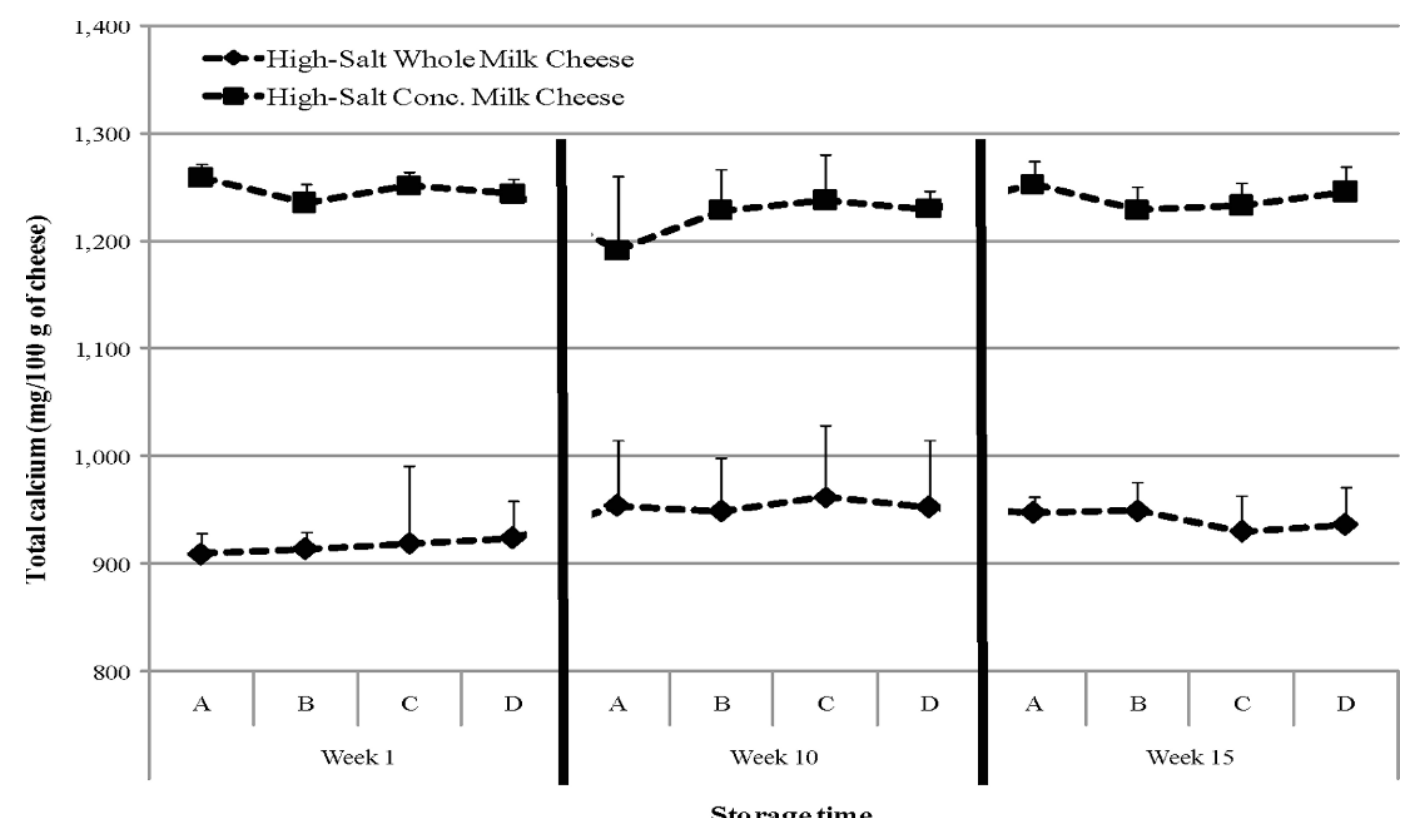

Figure 11. Changes in total calcium concentration in high-salt whole milk and high-salt concentrated milk cheeses at different positions in the cheese cylinder (with A being the innermost sample and D being the surface) throughout 15 wk of storage (mean of vacuum-packaged and gas-flushed packaged cheese; mean of duplicates).

value of total calcium in whole milk cheeses $(930 \mathrm{mg} /$ $100 \mathrm{~g}$ ) was larger than the values observed by other researchers in whole milk cheeses $(680$ to $833 \mathrm{mg} / 100$ g; Hassan et al., 2004; Swearingen et al., 2004) and can be explained by seasonal variation in the caseinto-calcium ratio in cheese milk (Dybing et al., 1988).

The concentration of soluble calcium in cheeses was influenced more by $\mathrm{pH}$ of cheeses than by protein con-

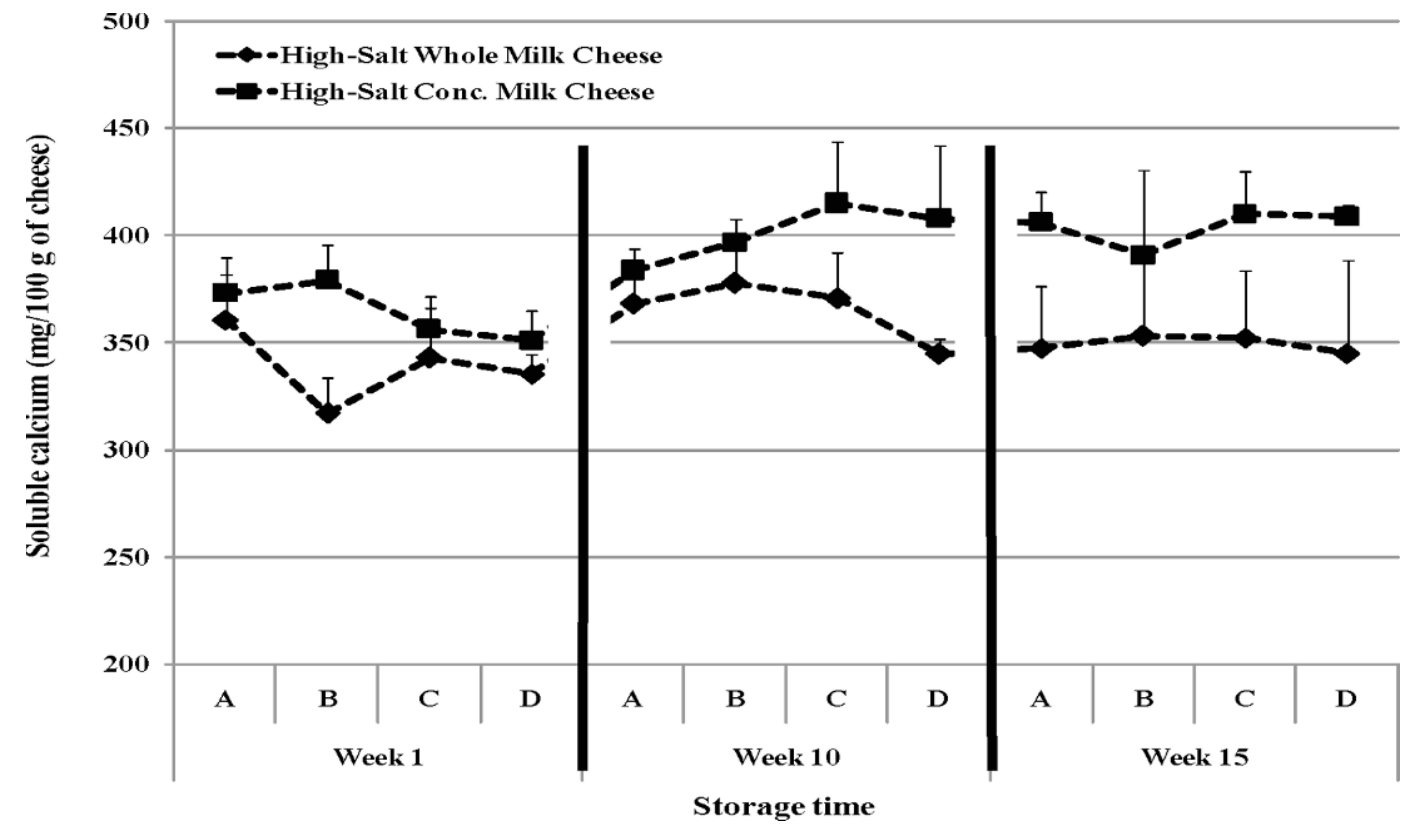

Figure 12. Changes in soluble calcium concentration in high-salt whole milk and high-salt concentrated milk cheeses at different positions in the cheese cylinder (with A being the innermost sample and D being the surface) throughout 15 wk of storage (mean of vacuum-packaged and gas-flushed packaged cheese; mean of duplicates). 


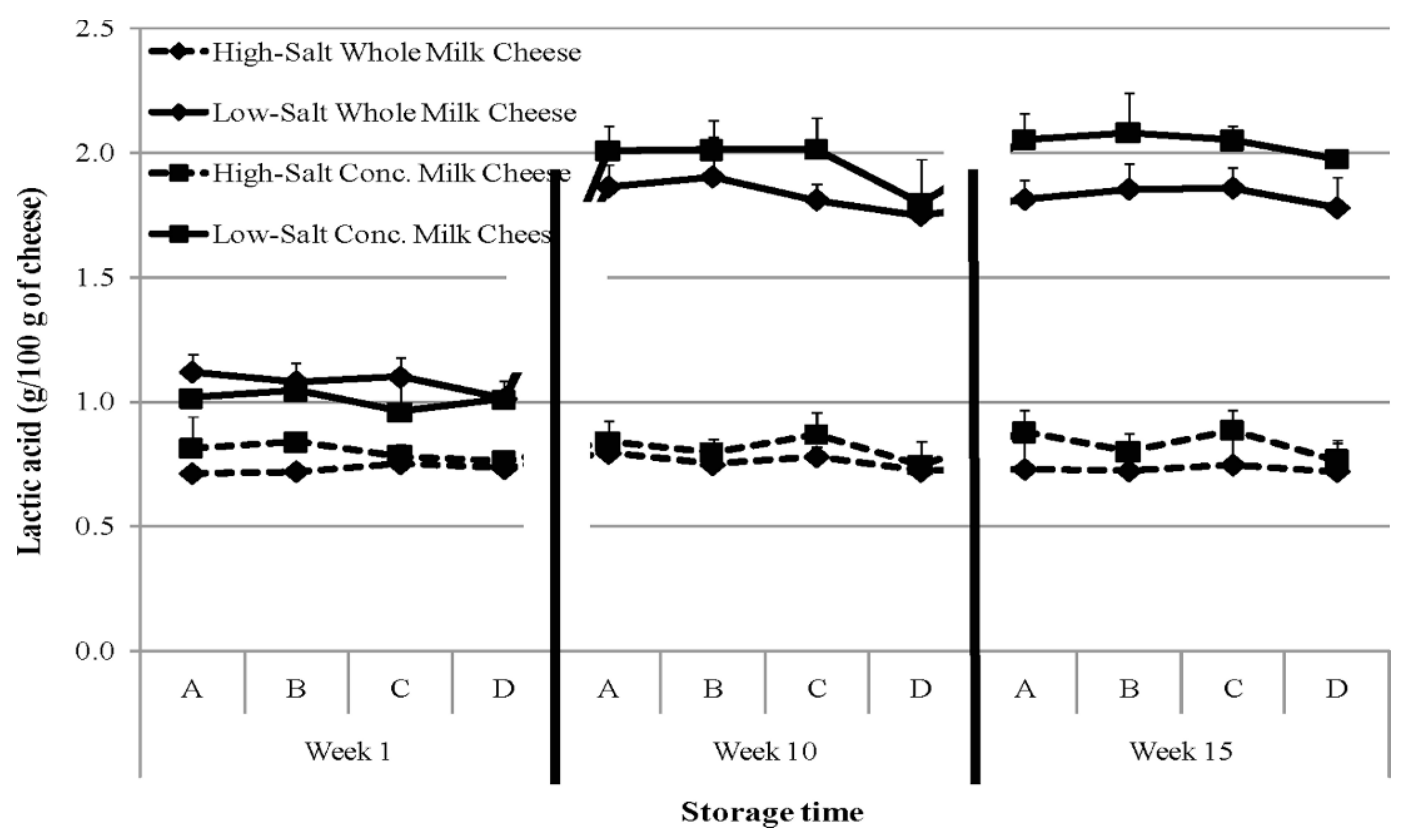

Figure 13. Changes in total lactic acid concentration in both high- and low-salt whole milk and concentrated milk cheeses at different positions in the cheese cylinder (with A being the innermost sample and D being the surface) throughout 15 wk of storage (mean of vacuumpackaged and gas-flushed packaged cheese; mean of duplicates).

centration of milk used for manufacturing. Mean soluble calcium content in high S:M cheeses (HSWMC and HSCMC; 351.20 and $387.30 \mathrm{mg} / 100 \mathrm{~g}$ of cheese) was lower than in low S:M cheeses (LSWMC and LSCMC; 496.33 and $524.13 \mathrm{mg} / 100 \mathrm{~g}$ of cheese; Figure 7). Because high S:M concentration inhibited culture metabolism, $\mathrm{pH}$ remained high and soluble calcium remained lower in cheeses, even though cheeses were salted at $\mathrm{pH}$ 5.40. Low $\mathrm{pH}$ and concentration of cheese milk leads to increased concentration of soluble calcium in cheeses. The soluble calcium levels in experimental cheeses were comparable to the soluble calcium values in the commercial cheeses (approximately $450 \mathrm{mg} / 100 \mathrm{~g}$ of cheese) studied by Swearingen et al. (2004). Salt had a significant effect on the amount of soluble calcium, because S:M directly affected the activity of SLAB, and thus the $\mathrm{pH}$ and lactic acid concentration of cheese. A correlation $(\mathrm{r}=0.81)$ was observed between amount of total lactic acid in cheese and amount of soluble calcium at the end of $15 \mathrm{wk}$ of aging. In addition, a correlation $(\mathrm{r}=0.83)$ was observed between $\mathrm{pH}$ of cheese and soluble calcium at the end of $15 \mathrm{wk}$ of aging. Concentration of soluble calcium increased significantly $(P<0.05)$ during the first 15 wk of aging in low S:M cheeses (LSWMC and LSCMC), whereas no significant changes were observed in high S:M cheeses (HSWMC and HSCMC; Table 2). Changes in lactic acid, $\mathrm{pH}$, and soluble calcium were correlated, such that cheeses with low S:M had increased concentration of lactic acid, lower $\mathrm{pH}$, and in- creased concentration of soluble calcium compared with cheeses with high S:M. Similar results were obtained by Agarwal et al. (2006a), who showed increased concentrations of soluble calcium and lactic acid with a decrease in cheese $\mathrm{pH}$ (5.4 to 4.8). Effects of S:M on lactic acid, $\mathrm{pH}$, and soluble calcium were also discussed in detail by Upreti and Metzger (2007), who found that cheeses with high S:M had decreased concentrations of soluble calcium and inorganic acids compared with cheeses with low S:M. Upreti and Metzger (2007) also found a high correlation $(\mathrm{r}=0.78)$ between $\mathrm{pH}$ of cheese and soluble calcium. To decrease the amount of soluble calcium and increase the $\mathrm{pH}$ of cheese, cheese manufacturers can introduce a washing step before the milling of cheese curd. The washing step will draw out excess lactose, lactic acid, and soluble calcium from the cheese and significantly lower the risk of having excessive lactic acid and calcium for CLC to occur, but will add to the increased cost of processing whey.

\section{Effect of Cheese Milk Composition, Salt, and Packaging on the Occurrence of CLC}

The CLC were detected earlier in cheeses with low salt that had low $\mathrm{pH}$ (below 5.1) compared with cheeses with high salt that had higher $\mathrm{pH}$ (above 5.3), regardless of milk type (Figure 8). The CLC began appearing at a light intensity on low S:M cheeses, in particular LSWMC and LSCMC that were gas flushed, as early 
as 5 wk ( 2 on a scale of 1 to 10 ; Table 3 ). At the end of 10 wk of aging, $\mathrm{pH}$ of all low S:M cheeses ranged from 4.9 to 5.1 and an increased intensity of CLC were observed in all these cheeses. Generally, increased intensities of CLC were observed in LSCMC compared with LSWMC. Additionally, low $\mathrm{pH}$ in cheeses led to a defect called sweating, which occurs because of the loss in moisture-holding capacity of cheese protein at low $\mathrm{pH}$ (Swearingen et al., 2004). Cheese packaging had no significant effect on the amounts of total calcium, soluble calcium, or lactic acid or on the salt concentration or $\mathrm{pH}$ of the cheeses, which was also seen by Agarwal et al. (2006b), suggesting that a loose package or a gasflushed package does not affect the cheese chemically. The CLC were observed earlier and to a greater extent in cheeses that were gas flushed (crystal intensity of 4 to 6) compared with cheeses that were vacuum packaged (crystal intensity of 2 to 3), probably because of loss of moisture to the surrounding air, which led to concentrations of calcium ions and lactate on the cheese surfaces (Table 3). The CLC were also observed at a higher intensity in cheeses made from concentrated milk compared (crystal intensity of 6) with cheeses made from whole milk (crystal intensity of 4 ) because of increased concentrations of soluble calcium and total lactic acid (Table 2). The CLC were observed in cheeses that had low $\mathrm{S}: \mathrm{M}$ but not in cheeses that had high S:M, showing the important relationship between salting rate and starter bacteria selection. Similar conclusions were also drawn by Rajbhandari and Kindstedt (2005), who held withinvat variation in salting efficacy responsible for the formation of CLC. L(+)-Lactate was the predominant form of lactate, and no $\mathrm{D}(-)$-lactate was determined from the analysis of CLC in the present study.

\section{Migration of Total and Soluble Calcium During Aging}

Significant $(P<0.05)$ differences were observed not only in the composition of cheeses having low and high $\mathrm{S}: \mathrm{M}$, but also in the way calcium and lactate ions migrated to the surface, leading to the development of CLC. Changes in total calcium, soluble calcium, and total lactic acid were studied at different concentric locations over 15 wk of aging. Significantly $(P<0.05)$ higher concentrations of total calcium were observed on the surface (position D) of LSWMC and LSCMC than at the core (positions A, B, and C) of the same cheeses after 15 wk of aging (Figure 9 ). In addition, significantly $(P<0.05)$ increased concentrations of total calcium were observed at wk 10 and 15 between positions D and C (Figure 9). This shows that most of the calcium that migrated to the surface had migrated from surrounding areas within the cheese (position $\mathrm{C})$. Significantly $(P<$
$0.05)$ increased concentrations of soluble calcium were observed within (positions A, B, and C) low S:M cheeses compared with on the surface (position D) after 10 and 15 wk of aging (Figure 10). Increased concentrations of soluble calcium and total lactic acid within the cheeses (positions A, B, and C) compared with on the surface (position D) suggest that gradients may encourage migration of calcium ions to the surface. The gradient theory is supported by the fact that no differences in high S:M cheeses were noted because no gradient existed. The occurrence of CLC on the surface of low S:M cheeses (LSWMC and LSCMC) can explain the increased concentration of total calcium on the surface compared with in other parts of the cheeses.

No significant differences in concentrations of total calcium, soluble calcium, and total lactic acid were observed between the core and surface of high S:M cheeses (HSWMC and HSCMC) after 10 and 15 wk of aging (Figures 11, 12, and 13). This lack of gradient in high S:M cheeses (HSWMC and HSCMC) can be explained by the lack of fermentation of lactose by starter bacteria, leading to insufficient soluble calcium and lactate in cheese serum to form CLC.

\section{CONCLUSIONS}

Results of this study suggest that cheese manufacturers must carefully select starter bacteria and must carefully monitor the salting of cheese during manufacture. The use of salt-tolerant SLAB enables postpress fermentation of residual lactose, solubilization of calcium, and CLC formation, particularly at low S:M and increased protein concentrations and in gas-flushed packaging conditions. Cheese manufacturers can reduce the occurrence of CLC in cheeses by selecting starter cultures that are salt sensitive, carefully monitoring the salting process for uniform distribution of salt, and carefully documenting postmanufacture $\mathrm{pH}$ of cheese during storage. Cheese manufacturers facing problems with CLC can consider reducing the concentrations of total and soluble calcium in the final cheese, which can be accomplished by introducing a curd-washing step.

\section{ACKNOWLEDGMENTS}

Appreciation is extended to David McCoy from Chr. Hansen Inc. for providing the commercial starter cultures. We also are grateful to Marc Evans for the help provided in analyzing data using SAS. Appreciation is extended to the WSU Creamery managers, Russ Salvadalena, Nial Yager, and John Haugen, for use of the pilot plant facilities. Gratitude is also extended to Jaydeep M. Chauhan for his immense help during cheese making. The authors appreciate the funding and 
support provided by the Washington State Dairy Products Commission (Lynnwood, WA).

\section{REFERENCES}

Acharya, M. R., and V. V. Mistry. 2004. Comparison of effect of vacuum-condensed and ultrafiltered milk on Cheddar cheese. J. Dairy Sci. 87:4004-4012.

Agarwal, S., M. Costello, and S. Clark. 2005. Gas-flushed packaging contributes to calcium lactate crystals in Cheddar cheese. J. Dairy Sci. 88:3773-3783.

Agarwal, S., J. R. Powers, B. G. Swanson, S. Chen, and S. Clark. 2006a. Cheese $\mathrm{pH}$, protein concentration, and formation of calcium lactate crystals. J. Dairy Sci. 89:4144-4155.

Agarwal, S., K. Sharma, B. G. Swanson, G. Ü. Yüksel, and S. Clark. 2006b. Nonstarter lactic acid bacteria biofilms and calcium lactate crystals in Cheddar cheese. J. Dairy Sci. 89:1452-1466.

Blake, A. J., J. R. Powers, L. O. Luedecke, and S. Clark. 2005. Enhanced lactose cheese milk does not guarantee calcium lactate crystals in finished Cheddar cheese. J. Dairy Sci. 88:2302-2311.

Chou, Y. E., C. G. Edwards, L. O. Luedecke, M. P. Bates, and S. Clark. 2003. Nonstarter lactic acid bacteria and aging temperature affect calcium lactate crystallization in Cheddar cheese. J. Dairy Sci. 86:2516-2524.

Dybing, S. T., S. A. Brudvig, J. A. Wiegand, and E. A. Huang. 1986. A simple method for estimating the extent of surface crystal development on colored Cheddar cheese. J. Food Prot. 49:421-422.

Dybing, S. T., J. A. Wiegand, S. A. Brudvig, E. A. Huang, and R. C. Chandan. 1988. Effect of processing variables on the formation of calcium lactate crystals on Cheddar cheese. J. Dairy Sci. $71: 1701-1710$.

Fox, P. F., L. H. McSweeney, M. T. Cogan, and P. Guinee. 2004. Cheese: Chemistry, Physics and Microbiology. Vol. 2. 3rd ed. Elsevier Academic Press, London, UK.

Hassan, A., M. E. Johnson, and J. A. Lucey. 2004. Changes in the proportions of soluble and insoluble calcium during the ripening of Cheddar cheese. J. Dairy Sci. 87:854-862.

Jensen, L. A., M. E. Johnson, and N. F. Olson. 1987. Composition and properties of cheeses from milk concentrated by ultrafiltration and reverse osmosis-A review of literature. Cult. Dairy Prod. J. 22:6-10, 12-14.

Johnson, M. E. 2004. Calcium Lactate Crystals. Intl. Cheese Technol. Exposition, Madison, WI.

Johnson, M. E., B. A. Riesterer, and N. F. Olson. 1990b. Influence on nonstarter bacteria on calcium lactate crystallization on the surface of Cheddar cheese. J. Dairy Sci. 73:1145-1149.

Khalid, N. M., and E. H. Marth. 1990. Lactobacilli-Their enzynes and role in ripening and spoilage of cheese: A review. J. Dairy Sci. 73:2669-2684.

Kuehl, R. O. 2000. Design of Experiments: Statistical Principles of Research Design and Analysis. 2nd ed. Duxbury Press, Pacific Grove, CA.
Kubantseva, N., R. W. Hartel, and P. A. Swearingen. 2004. Factors affecting solubility of calcium lactate in aqueous solutions. J. Dairy Sci. 87:863-867.

Lee, M. R., M. E. Johnson, and J. A. Lucey. 2005. Impact of modifications in acid development on the insoluble calcium content and rheological properties of Cheddar cheese. J. Dairy Sci. 88:3798-3809.

Linke, W. F. 1958. Solubilities of Inorganic and Metal Organic Compounds. 4th ed. W. F. Linke, ed. Am. Chem. Soc., Washington, DC.

Marshall, R. T. 1992. Standard Methods for the Examination of Dairy Products. 16th ed. American Public Health Association, Wshington, DC.

McDowall, F. H., and A. K. R. McDowell. 1939. The white particles in mature Cheddar cheese. J. Dairy Res. 10:118-119.

O'Connor, C. B. 1974. The quality and composition of Cheddar cheese: Effect of various rates of salt addition. III. Ir. Agric. Cream Rev. 27:11-13.

Pearce, K. N., L. K. Creamer, and J. Gilles. 1973. Calcium lactate deposits on rindless Cheddar cheese. N. Z. J. Dairy Sci. Technol. $8: 3-7$.

Rajbhandari, P., and P. S. Kindstedt. 2005. Compositional factors associated with calcium lactate crystallization in smoked Cheddar cheese. J. Dairy Sci. 88:3737-3744.

Robinson, R. K., and R. A. Wilbery. 1998. Cheesemaking Practice. 3rd ed. Aspen Publisher, Inc. Gaithersburg, MD.

Severn, D. J., M. E. Johnson, and N. F. Olson. 1986. Determination of lactic acid in Cheddar cheese and calcium lactate crystals. J. Dairy Sci. 69:2027-2030.

Shakeel Ur, R., J. M. Banks, P. L. H. McSweeney, and P. F. Fox. 2000. Effect of ripening temperature on the growth and significance of non-starter lactic acid bacteria in Cheddar cheese made from raw of pasteurized milk. Int. Dairy J. 10:45-53.

Somers, E. B., M. E. Johnson, and A. C. L. Wong. 2001. Biofilm formation and contamination of cheese by nonstarter lactic acid bacteria in the dairy environment. J. Dairy Sci. 84:1926-1936.

Swearingen, P. A., D. E. Adams, and T. L. Lensmire. 2004. Factors affecting calcium lactate and liquid expulsion defects in Cheddar cheese. J. Dairy Sci. 87:574-582.

Thomas, T. D., and V. L. Crow. 1983. Mechanism of D(-)-lactic acid formation in Cheddar cheese. N. Z. J. Dairy Sci. Technol. 18:131-141.

Thomas, T. D., and K. N. Pearce. 1981. Influence of salt on lactose fermentation and proteolysis in Cheddar cheese. N. Z. J. Dairy Sci. Technol. 16:253-259.

Turner, K. W., and T. D. Thomas. 1980. Lactose fermentation in Cheddar cheese and the effect of salt. N. Z. J. Dairy Sci. Technol. 15:265-276

Upreti, P., L. L. McKay, and L. E. Metzger. 2006. Influence of calcium and phosphorus, lactose, and salt-to-moisture ratio on Cheddar cheese quality: Changes in residual sugars and water-soluble organic acids during ripening. J. Dairy Sci. 89:429-443.

Upreti, P., and L. E. Metzger. 2007. Influence of calcium and phosphorus, lactose, and salt-to-moisture ratio on Cheddar cheese quality: pH changes during ripening. J. Dairy Sci. 90:1-12. 